\title{
Soil carbon dioxide efflux in conilon coffee (Coffea canephora Pierre ex A. Froehner) plantations in different phenological phases in tropical climate in Brazil
}

\author{
Yago T. da Vitória ${ }^{1}$, Marta Cristina T. Leite ${ }^{1}$, Rafael C. Delgado ${ }^{2}$, Grazielle F. Moreira ${ }^{1}$, \\ Evandro C. de Oliveira ${ }^{1}$, Waylson Z. Quartezani ${ }^{3}$, and Ramon A. de Sales ${ }^{4 *}$ \\ 'Instituto Federal de Educação, Ciência e Tecnologia do Espírito Santo, Campus Itapina, CEP: 29700-970, Colatina, Espírito \\ Santo, Brasil. \\ ${ }^{2}$ Universidade Federal Rural do Rio de Janeiro, CEP 23890-000, Seropédica, Rio de Janeiro, Brasil. \\ ${ }^{3}$ Instituto Federal de Educação, Ciência e Tecnologia do Espírito Santo, Santo, Campus Montanha, CEP: 29890-000, Montanha, \\ Espírito Santo, Brasil. \\ ${ }^{4}$ Universidade Federal de Viçosa, Departamento de Fitotecnia, CEP: 36570 900, Viçosa, Minas Gerais, Brasil. \\ "Corresponding author (ramonamarodesales@gmail.com).
}

Received: 9 November 2018; Accepted: 26 March 2019; doi:10.4067/S0718-58392019000300366

\begin{abstract}
The agricultural sector is considered an important source of greenhouse gases, in which the coffee crop has an important contribution, participating in the dynamics of soil $\mathrm{C}$ and $\mathrm{CO}_{2}$ emissions. In this way, the aim of this study was to analyze and quantify $\mathrm{CO}_{2}$ emissions in different phenological phases in soil cultivated with conilon coffee (Coffea canephora Pierre ex A. Froehner), and compare it with $\mathrm{CO}_{2}$ flow in forest and pasture area. The experiment was conducted in the Experimental Area of the Federal Institute of Espírito Santo, Southeastern Brazil, in an experimental plot of 0.5 ha cultivated with conilon Vitória coffee clones. The quantification of soil $\mathrm{CO}_{2}$ flux was performed between July 2016 and June 2017, this period comprising all the seasons of the year, using in two rounds of ratings (day and night), with five replicates each. For comparison purposes, another measurement of the $\mathrm{CO}_{2}$ stream was conducted in June 2017 with an evaluation period of $24 \mathrm{~h}$. The highest $\mathrm{CO}_{2}$ emission occurred during the harvest phases of the fruit $\left(206.7 \mathrm{mg} \mathrm{CO}_{2} \mathrm{~m}^{-2} \mathrm{~h}^{-1}\right)$. The lowest daily $\mathrm{CO}_{2}$ flow records were observed in the rest and flowering phases with values of 82.1 and $83.6 \mathrm{CO}_{2} \mathrm{mg} \mathrm{m}^{-2} \mathrm{~h}^{-1}$, respectively. The $\mathrm{CO}_{2}$ emission from the forest was higher than the emissions that occurred in the area planted with conilon coffee and pasture, during dry season.
\end{abstract}

Key words: Agricultural culture, basal respiration, $\mathrm{CO}_{2}$, phenology.

\section{INTRODUCTION}

Climate change has caused increasing concern worldwide due to the high emissions of anthropogenic carbon dioxide $\left(\mathrm{CO}_{2}\right)$ and its residence time in the atmosphere being the focus of many recent studies with the aim of understanding its causes and consequences (Chang et al., 2016; Raj, 2016; Arneth et al., 2017; Dryden et al., 2017).

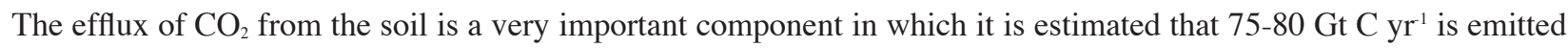
globally into the atmosphere (Drake et al., 2012). Therefore, this high amount of released $\mathrm{CO}_{2}$ can exert a great influence in increasing the concentration of this gas in the atmosphere, which can promote disturbing climatic changes, causing direct and indirect impacts on the agroecosystems and in particular on the growth and development of the plants (Panosso et al., 2011; Zheng et al., 2014; Silva et al., 2017). 
The agriculture sector is indicated as an important emitting source of greenhouse gas (GHG), but it can behave like atmospheric $\mathrm{CO}_{2}$ drainage with the process of photosynthesis, depending on the management and agricultural practices applied to the soil (Forkel et al., 2016; Stout et al., 2016). In Brazil, the main source of $\mathrm{CO}_{2}$ emissions are land use and management practices, accounting for $76 \%$ of $\mathrm{CO}_{2}$ emissions (Brasil, 2009). Several studies report that the elevated rate of soil $\mathrm{CO}_{2}$ efflux are strongly related to the conditions of higher temperature and soil moisture (Jia et al., 2018).

Coffee plantations among other economic segments are also responsible for GHG emissions (Belizário, 2013). The conilon/robusta coffee (Coffea canephora Pierre ex A. Froehner) exerts a significant influence on the socioeconomic and agribusiness aspects of the State of Espírito Santo, accounting for $76.58 \%$ of Brazilian conilon coffee production and $17.00 \%$ of the world's robusta coffee with cultivated area 286.371 ha, registered as the largest cultivated area of Brazil (CONAB, 2016).

Considering the importance of conilon coffee in the economy of the state of Espírito Santo, knowledge about the control of soil $\mathrm{CO}_{2}$ emissions in the different phenological stages of the coffee crop is fundamental, since relatively small changes in soil respiration rates can alter atmospheric concentrations $\mathrm{CO}_{2}$ sequestration rates, as well as soil $\mathrm{C}$ sequestration rates (Iqbal et al., 2009).

In addition, such information provides us with important indications of root and microbial processes as well as enable us to establish sustainable land use models and to estimate global C fluxes that affect climate change, and these processes are strongly related to the characteristics edaphic and climatic conditions (Buysse et al., 2016; Ferreira et al., 2018). Thus, this study aims to analyze and quantify $\mathrm{CO}_{2}$ emissions through temporal analysis during cultivation conilon coffee in the northwest of the state of Espírito Santo, Brazil.

\section{MATERIAL AND METHODS}

\section{Study area and climate}

Field experiments were conducted in the Experimental Area of the Federal Institute of Espírito Santo, Campus Itapina (IFES), Colatina (19³2'22” S, 40³7'50" W; 71 m a.s.l.), northwestern region of Espírito Santo, Brazil. The climate of the region is Tropical Aw, according to the climatic classification of Köppen. The region is characterized by irregular rainfall and high temperatures, with a well-defined rainy season occurring between October and January, and average climatological precipitation of $1029.9 \mathrm{~mm}$ (Sales et al., 2018).

\section{Characterization of the experimental area}

An experimental plot of 0.5 ha cultivated with the clonal var. conilon Vitória (Incaper 8142) (Coffea canephora Pierre ex A. Froehner) was used to quantify $\mathrm{CO}_{2}$ efflux. The plot consisted of 1974 plants aged 12 and $13 \mathrm{yr}$ (production of $3360 \mathrm{~kg}$ ha $^{-1}$ in 2012). Tillage was implanted in 2004 and 2005 in conventional planting system, with spacing of $3 \times 1 \mathrm{~m}$ and managed with sprinkler irrigation system applying, fortnightly, a water depth of $9.3 \mathrm{~mm} \mathrm{~h}^{-1}$ for $3 \mathrm{~h} \mathrm{~d}^{-1}$. The chemical fertilization, pruning and post-harvest treatment were performed according to the technical recommendations for the crop (Ferrao et al., 2007). The control of spontaneous vegetation was carried out with the application of glyphosate, however since 2009 this control method was modified for mechanical management (mowing). The spontaneous vegetation was left in the area after mowing as a source of organic matter, characterizing a conservationist practice. The soil of the experimental area is classified as Dystrophic Red-Yellow Latosol (Embrapa, 2013) and the chemical characteristics are presented in Table 1.

\section{Soil $\mathrm{CO}_{2}$ emissions}

The quantification of the $\mathrm{C}_{-} \mathrm{CO}_{2}$ flux was carried out monthly by the chemical method with trap of alkalis, during the period of rest, flowering, fruit granulation, fruit maturation and harvest of the branches (12-mo). The evaluations were realized in two shifts (day and night) with five replicates each.

Large-aperture glass vials containing $10 \mathrm{~mL} 0.5 \mathrm{~N} \mathrm{NaOH}$ solution were placed on the soil, opened and immediately covered with a black plastic bucket with a capacity of $22 \mathrm{~L}$ of cylindrical shape, covering a soil area of $697.46 \mathrm{~cm}^{2}$. The edges of the plastic bucket were buried in the ground for about $3 \mathrm{~cm}$ deep pile and soil around the bucket to prevent contamination with atmospheric $\mathrm{CO}_{2}$. During the day shift, the bottles remained in the coffee area from 07:00 to 17:00 $\mathrm{h}$ $(10 \mathrm{~h})$ and at night from 17:00 to 07:00 $\mathrm{h}(14 \mathrm{~h})$. 
Table 1. Soil chemical attributes of the experimental area in depth of 0-20 cm.

\begin{tabular}{|c|c|c|c|c|c|c|c|c|c|c|c|c|c|c|}
\hline ID & $\mathrm{pH}$ & P-rem & $\mathrm{OM}$ & $\mathrm{P}$ & K & $\mathrm{Ca}$ & $\mathrm{Mg}$ & $\mathrm{Al}$ & $\mathrm{H}+\mathrm{Al}$ & SB & $\mathrm{T}$ & $\mathrm{t}$ & $\mathrm{m}$ & $\mathrm{V}$ \\
\hline & & $\mathrm{mg} \mathrm{L}^{-1}$ & $\%$ & \multicolumn{2}{|c|}{$\mathrm{mg} \mathrm{dm}^{-3}$} & \multicolumn{7}{|c|}{$\mathrm{cmol}_{\mathrm{c}} \mathrm{dm}^{-3}$} & \multicolumn{2}{|c|}{$-\%$} \\
\hline Coffee & 6.4 & 36.8 & 3.1 & 12.4 & 89.0 & 4.7 & 1.8 & 0.0 & 2.3 & 6.7 & 8.9 & 6.7 & 0.0 & 74.7 \\
\hline Pasture & 6.3 & 29.0 & 2.1 & 40.1 & 451.0 & 5.3 & 1.5 & 0.0 & 3.0 & 7.9 & 11.0 & 7.9 & 0.0 & 72.4 \\
\hline Forest & 6.7 & 37.0 & 1.7 & 14.3 & 230.0 & 4.8 & 2.3 & 0.0 & 1.8 & 7.6 & 9.4 & 7.6 & 0.0 & 80.6 \\
\hline
\end{tabular}

Extractor: Mehlich 1.

ID: Identification; OM: organic matter; P-rem: P-residual; SB: sum of bases; T: cation exchange capacity (CEC) of pH 7; t: effective CEC; m: Al saturation; V: base saturation.

After the evaluation period of each shift, flasks were quickly collected, closed and taken to the Chemistry Laboratory of the IFES for the titration with $0.1 \mathrm{M} \mathrm{HCl}$ solution using a solution of phenolphthalein $1 \%$. In each flask was added 1 $\mathrm{mL}$ barium chloride in order to precipitate the captured $\mathrm{CO}_{2}$ avoiding its loss to atmosphere. As a control, a vial submitted to the same conditions described above, but hermetically sealed was used. The same titration process described was also applied to the control flasks.

The $\mathrm{CO}_{2}$ mass released per unit area and time $\left(\mathrm{mg} \mathrm{m}^{-2} \mathrm{~h}^{-1}\right)$ was calculated considering the total $\mathrm{CO}_{2}$ mass released during the stay under the bucket and its area of coverage.

$$
\mathrm{CO}_{2}=\left\{\left[(\mathrm{VB}-\mathrm{VA}) \times \mathrm{NHCl} \times \mathrm{Fc} \times \mathrm{Eq} \mathrm{CO}_{2}\right] / \mathrm{A} \times \mathrm{T}\right\} \times 10^{4} \times 4 / 3
$$

where, $V B$ is the difference in volumes of hydrochloric acid spent in titration of blank; $V A$ is difference in volumes of hydrochloric acid spent in titration of the sample; $\mathrm{NHCl}$ is normality of hydrochloric acid $(0.1) ; \mathrm{Fc}$ is hydrochloric acid correction factor; $\mathrm{EqCO} \mathrm{CO}_{2}$ is $\mathrm{CO}_{2}$ gram equivalent (22); $\mathrm{A}$ is coverage area of the bucket; $10^{4}$ is transformation area $\left(\mathrm{m}^{2}\right) ; T$ is collection time (h); $4 / 3$ is the factor that corrects the efflux value of $\mathrm{CO}_{2}$ that is underestimated in $25 \%$ by chemical method.

Concomitantly with soil $\mathrm{CO}_{2}$ efflux measurements, soil temperature and soil moisture were determined. The soil temperature was measured using the digital thermometer (Incoterm, Porto Alegre, Brazil) at a depth of $10 \mathrm{~cm}$, while the soil moisture was determined with the electronic soil moisture meter (HidroFarm, Falker, Porto Alegre, Rio Grande do Sul, Brazil), which performs the measurement of soil moisture by the high frequency soil impedance (ISAF) in depth from 0 to $20 \mathrm{~cm}$. Soil temperature and humidity were recorded at 07:00 h in all monthly evaluations in coffee area and at 17:00 $\mathrm{h}$ in the evaluations of $\mathrm{C}-\mathrm{CO}_{2}$ emissions in coffee plantation, pasture and forest. Meteorological variables, such as temperature, relative humidity and rainfall were obtained through the automatic meteorological station located near the experimental field of the IFES.

To determine the aerial biomass production, three samples were collected for each month, except for the months of July, August, September and October 2016. Sampling was performed randomly, between the lines of planting, using a wooden frame of $0.16 \mathrm{~m}^{2}$.

In order to complement this study, $\mathrm{CO}_{2}$ flow measurements were performed in a coffee plantation (experimental area), in a Brachiaria sp. pasture (irrigated) and in an Atlantic forest area (natural regeneration phase, with arboreal individuals with height $(\mathrm{H})>3 \mathrm{~m}$ ), located on the banks of the Doce River, five collecting points in each area, on 8 June 2017 in a 24 $\mathrm{h}$ sampling period, during the dry season. The methodology used $(24 \mathrm{~h})$ was the same adopted in the evaluation of $\mathrm{CO}_{2}$ emissions in the period from July 2016 to June 2017. Soil temperature and humidity in the coffee plantation, forest and pasture were recorded at 07:00,07:30 and 08:00 $\mathrm{h}$.

\section{Statistical analysis}

The data were submitted to ANOVA by the F test and the means compared by the Tukey test at 5\% probability. Statistical analyses were performed using the software SPSS 15.0 (IBM, Armonk, New York, USA) and R 3.2.1. (R Foundation for Statistical Computing, Vienna, Austria).

\section{RESULTS AND DISCUSSION}

The temperature variations in the evaluated period were characteristic of the region, with minimum temperatures (Tmin) occurring in winter $\left(10.9^{\circ} \mathrm{C}\right)$, maximum (Tmax) in summer $\left(42.5^{\circ} \mathrm{C}\right)$ and intermediate (Tmed) in autumn and spring $\left(26.5^{\circ} \mathrm{C}\right)($ Figure 1A). Rainfall variations were also characteristic of the region, with great rainfall concentration at the 
Figure 1. Monthly averages of maximum, minimum and average air temperatures (A) and rainfall (B) at Colatina, Espírito Santo.
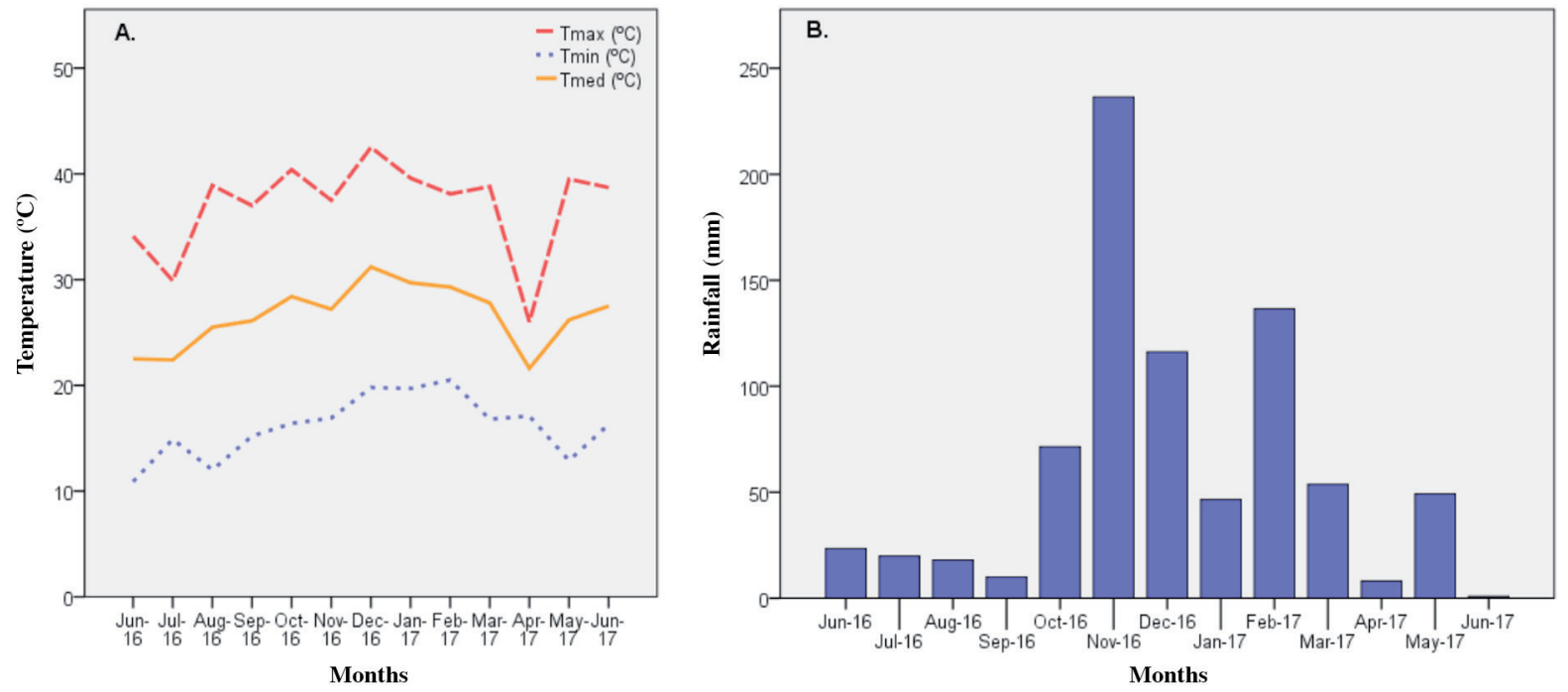

end of spring, remaining during the summer, which is the rainiest period of the region. The highest rainfall concentration occurred in November and December of 2016 and February of 2017, with 236.4, 116.1 and 136.5 mm, respectively, corresponding approximately two-thirds of the total annual precipitation (Figure 1B).

Assessing the average of $\mathrm{CO}_{2}$ emission of each phenological phases of conilon coffee, it was observed that during the daytime shift, the lowest respiratory activities were recorded in rest, flowering and fruit granulation phases, with values of 49.8, 66.6 and $58.4 \mathrm{CO}_{2} \mathrm{mg} \mathrm{m}^{-2} \mathrm{~h}^{-1}$, respectively. The highest efflux rates occurred on the phenological phases of fruit maturation and harvest, with values of 86.1 and $93.9 \mathrm{CO}_{2} \mathrm{mg} \mathrm{m}^{-2} \mathrm{~h}^{-1}$, respectively. In the night shift, the largest $\mathrm{CO}_{2}$ releases occur in the phenological phase of harvest with value of $89.2 \mathrm{CO}_{2} \mathrm{mg} \mathrm{m}^{-2} \mathrm{~h}^{-1}$, differing significantly from the others (Figure 2A). The last two phenological stages of coffee (fruit maturation e harvest) present an increase in biomass and natural deposition of vegetal residues due to fall of leaves, fruits and of branches eliminated with the pruning that remain in the crop as mulch. The efflux of $\mathrm{CO}_{2}$ in the night shift was always lower than daytime efflux, with significant difference in the phenological phases of rest and fruit maturation (Figure 2A), totaling during the cycle values of 308.0 and $354.8 \mathrm{CO}_{2} \mathrm{mg} \mathrm{m}^{-2} \mathrm{~h}^{-1}$, respectively, night and daytime (Figure 2B). Therefore, the decomposition and consequent release of $\mathrm{CO}_{2}$ may have been favored by solar radiation.

The lower $\mathrm{CO}_{2}$ outflow observed in night shift can be explained at least partly by the fall in temperature, which would reduce the microbial activity in the soil. According to studies by Kirschbaum (1995), the rate of decomposition of organic matter in the soil is higher as the temperature and humidity of the soil increases, giving off $\mathrm{CO}_{2}$, which is emitted to the atmosphere. Therefore, the decomposition and consequent release of $\mathrm{CO}_{2}$ may have been favored by solar radiation. In addition, Kirschbaum (1995) argue that rising temperatures lead to the long-term decline of $\mathrm{C}$ stored in the soil.

Analyzing the soil respiration in the conilon coffee (day + night) (Table 2), upon release of $\mathrm{CO}_{2}$ during the phenological phases evaluation, it was found that the average emitted was $132.2 \mathrm{mg} \mathrm{CO}_{2} \mathrm{~m}^{-2} \mathrm{~h}^{-1}$, with the highest $\mathrm{CO}_{2}$ emission during the harvest phase. The lowest daily $\mathrm{CO}_{2}$ flow records were observed in the rest and fruit granulation phases.

Soil moisture during 12-mo of evaluation presented an average of 21.4\%, being higher in February and May, while the lowest record was obtained in November (Table 2). It is worth mentioning that the recordings were made at the time of the spring equinox and summer solstice period of increased rainfall intensity (Figure 1B). The highest soil temperature was recorded in the summer, with $26^{\circ} \mathrm{C}$ for December 2016 and February 2017, and the minimum temperature was recorded in the spring, with $22^{\circ} \mathrm{C}$ for June.

The high $\mathrm{CO}_{2}$ emission observed during the harvest phase of the branches may be related to the increase of the microbial activity in the organic matter decomposition process, due to the increase of moisture and deposition of matter in the soil from the invading plants that were harvested, fall of fruits in the harvest, thinning and self-pruning. Currently, the 
Figure 2. $\mathrm{CO}_{2}$ emissions on day and night shifts during the phenological phases (A), and the accumulated $\mathrm{CO}_{2}$ emission in the day and night shifts (B), in an area planted with conilon coffee at Colatina, Espírito Santo.
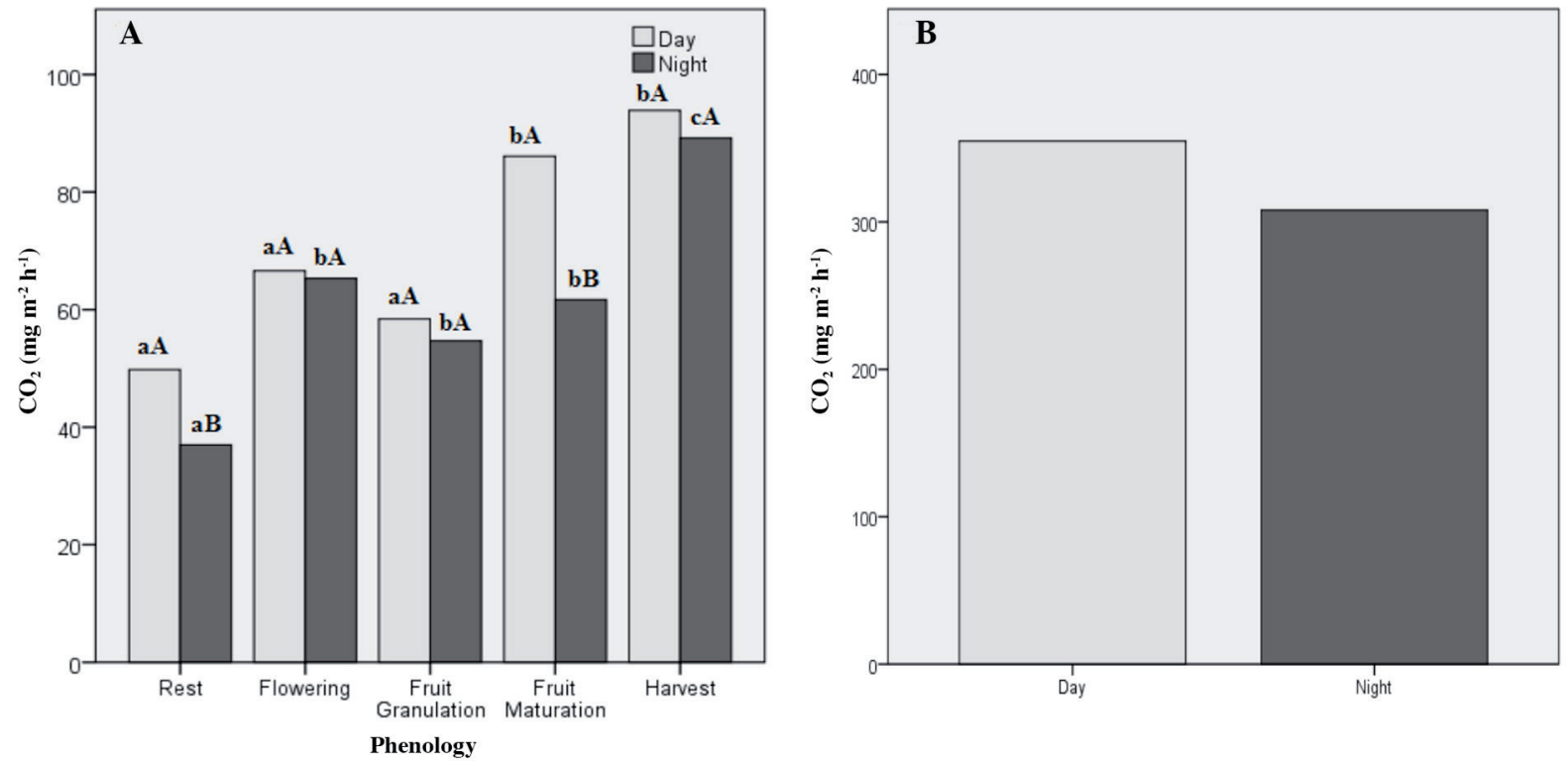

Averages followed by the same lower-case letter (difference among the phenological phases during the daytime and night) and capital letters (relation between daytime and night periods in each phenological phase) do not differ from each other by the Scott-Knott and T test, respectively, at $5 \%$ probability.

Table 2. Moisture and temperature soil and mean values of $\mathrm{CO}_{2}($ night + day) production in each phenological phase in the 12-mo of evaluation, in a conilon coffee area at Colatina, Espírito Santo.

\begin{tabular}{llccc}
\hline Phenology & Month & Soil moisture & Soil temperature & Day + Night \\
\hline \multirow{4}{*}{ Rest } & & $\%$ & ${ }^{\circ} \mathrm{C}$ & $\mathrm{CO}_{2} \mathrm{~m}^{-2} \mathrm{~h}^{-1}$ \\
& Jul/16 & 21.4 & 23.0 & 82.1 \\
Flowering & Aug/16 & 22.2 & 24.0 & 91.4 \\
& Average & 21.8 & 23.5 & 86.8 \\
& Sep/16 & 25.2 & 23.0 & 177.0 \\
Fruit granulation & Oct/16 & 16.8 & 23.0 & 83.6 \\
& Average & 21.0 & 23.0 & 130.3 \\
& Nov/16 & 12.0 & 25.0 & 117.9 \\
Fruit maturation & Dec/16 & 21.4 & 26.0 & 93.1 \\
& Jan/17 & 21.8 & 25.0 & 128.5 \\
& Average & 21.6 & 25.5 & 110.8 \\
& Feb/17 & 30.7 & 26.0 & 171.9 \\
& Mar/17 & 15.3 & 24.0 & 133.4 \\
Harvest & Apr/17 & 17.9 & 25.0 & 138.2 \\
& Average & 16.6 & 24.5 & 135.8 \\
& May/17 & 34.7 & 23.0 & 206.7 \\
& Jun/17 & 17.3 & 22.0 & 159.5 \\
& Average & 26.0 & 22.5 & 183.1 \\
& Total & - & - & 1583.3 \\
\hline
\end{tabular}

biosphere absorbs around $20 \%$ of $\mathrm{CO}_{2}$ emissions, but simulations of global vegetation models suggest that $\mathrm{CO}_{2}$ emissions from landscape changes are still poorly understood, since the effects of the harvesting processes, deforestation and the change in land use and land cover over time are not known (Arneth et al., 2017). 
In general, comparing monthly $\mathrm{CO}_{2}$ emissions with soil moisture, it was verified that these variables were related, with higher $\mathrm{CO}_{2}$ emissions in the months that the soil moisture was higher and vice versa (Figure 3). Similar results were found by McKnight et al. (2017), who showed that soil moisture also influenced $\mathrm{CO}_{2}$ fluxes in pasture and forest areas, finding a higher $\mathrm{CO}_{2}$ emission in the forest area. The same authors also concluded that although soil moisture plays an important role in soil $\mathrm{CO}_{2}$ flow rates among land use types, more research is needed on soil $\mathrm{C}$ loss mechanisms and how they are driven by changes in land use.

The mechanism of soil respiration is associated with soil moisture and temperature conditions, factors that are dependent on local climatic conditions and the management that is applied to the soil. Davidson et al. (2002) stated that sunny day after a rainy or irrigation period there is a significant increase in $\mathrm{CO}_{2}$ emission. This increase is due to the exit of $\mathrm{CO}_{2}$ present in the pores with water drainage. This fact may explain the large flow of $\mathrm{CO}_{2}$ that occurred in September, February and May.

The aerial biomass stock assessment showed significant highest average in March 2017 (83.3 g) and lower in November and December 2016, with 32.8 and 32.3 g biomass, respectively (Figure 4). Campana et al. (2007), analyzing the characteristics of litter in coffee (Coffea arabica L.) plantations in the Zona da Mata of Minas Gerais, Brazil, recorded for the agroforestry system mean litter deposition of $50.7 \mathrm{~g} \mathrm{~m}^{-2} \mathrm{DM}$ per month, significantly higher than $37.2 \mathrm{~g} \mathrm{~m}^{-2}$ verified in monoculture. Note that there is an increase in biomass production over the months that may be related to greater intensity of coffee leaves drop in the coffee fruit ripening season constituting strong drains for photoassimilates.

In this study, it may be noted the relationship between the flow of $\mathrm{CO}_{2}$ and biomass stock for the stages of fruit granulation, fruit maturation and harvest, in which higher biomass stocks coupled with humidity can be led to a greater $\mathrm{CO}_{2}$ emission (Figure 5). The fact that the biomass flow and biomass stock did not show a relationship in the maturation phase may be due to the low humidity that occurred in those two months, since soil moisture is the main factor responsible for net primary productivity and therefore strongly affects soil carbon accumulation and cycle (Moyano et al., 2013). La Scala et al. (2006) also find relationship between the $\mathrm{CO}_{2}$ flow and the aerial biomass stock in areas of native forest and sugar cane, respectively. Oliveira et al. (2013), and Signor et al. (2014) also reported a positive relationship between soil $\mathrm{CO}_{2}$ emissions and organic matter content, which is related to the addition of plant residues.

Analyzing the $\mathrm{CO}_{2}$ medium flows in the coffee area, grassland and forest which occurred on 8 June 2017, it was observed that the average $\mathrm{CO}_{2}$ flux from the forest were $83.7 \mathrm{mg} \mathrm{m}^{-2} \mathrm{~h}^{-1}$, being higher than the emissions that occurred in the area cultivated with conilon coffee and pasture, with values of 58.8 and $62.9 \mathrm{mg} \mathrm{CO}_{2} \mathrm{~m}^{-2} \mathrm{~h}^{-1}$, respectively (Table 3). It is worth mentioning that the evaluation was done in the dry season at the end of autumn and that the present study

Figure 3. $\mathrm{CO}_{2}$ emissions per month (day + night) related to soil moisture (\%) at 12 months of sampling acreage with conilon coffee, at Colatina, Espírito Santo.

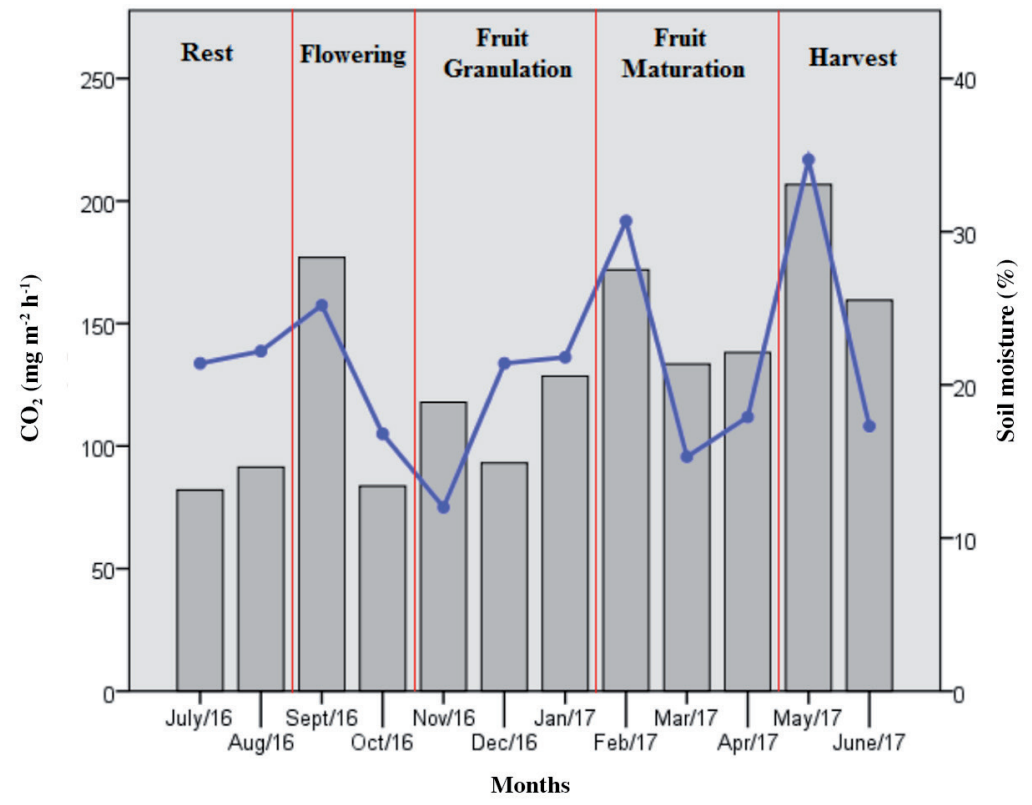


Figure 4. Average biomass (g) collected in area under conilon coffee at Colatina, Espírito Santo.

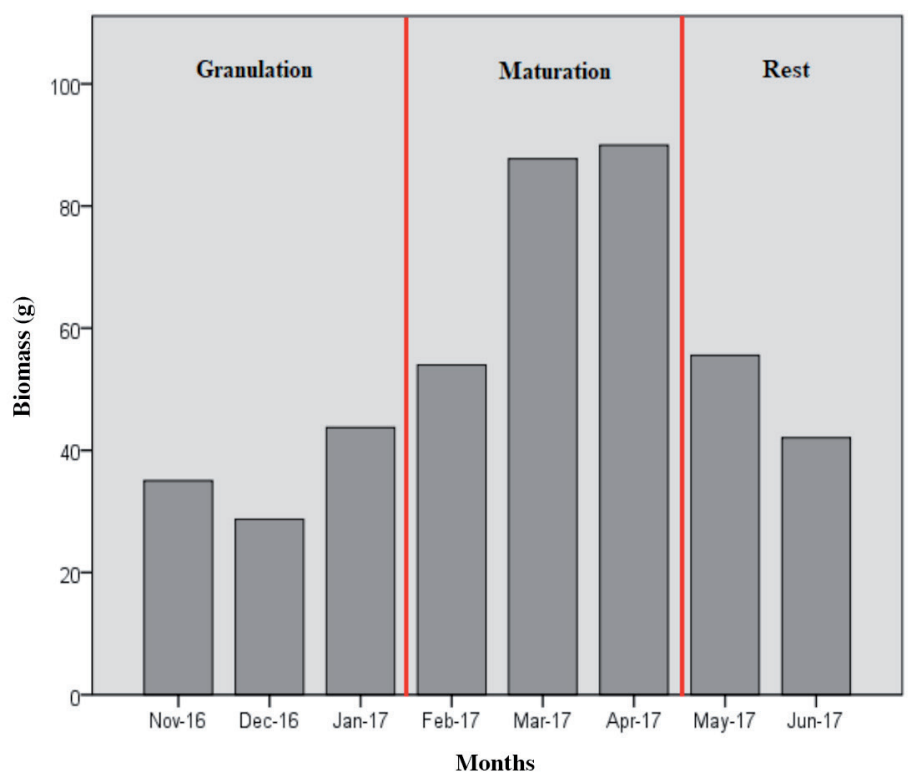

Figure 5. Monthly $\mathrm{CO}_{2}($ day + night) associated with biomass in area cultivated with conilon coffee at Colatina, Espírito Santo.

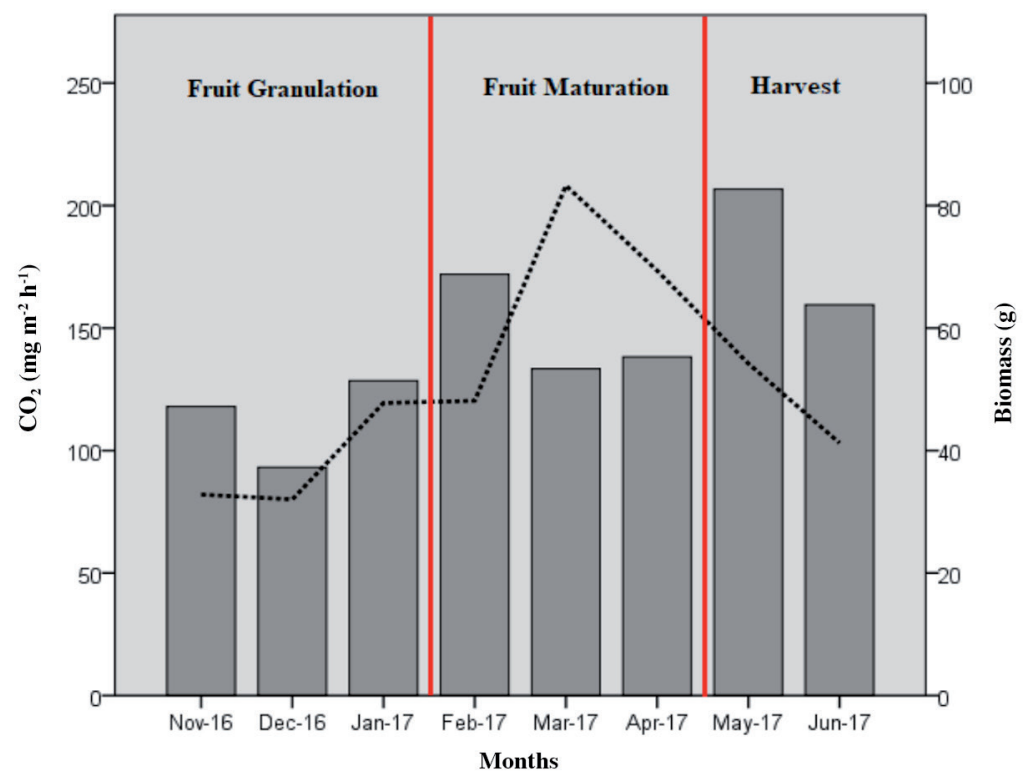

did not aim to measure absolute values of $\mathrm{CO}_{2}$, but only to establish comparisons between the $\mathrm{CO}_{2}$ emissions of the soil in the different vegetation cover.

This significant difference in $\mathrm{CO}_{2}$ efflux the forest area and the other areas can be attributed to the vegetation cover, which is a determinant factor on the microbial activity (Borges et al., 1999). In the horizons of forest soils, several factors must have contributed to the observed results, among them, the quality and quantity of vegetation (dead cover), organic matter content, litter thickness, soil moisture, species diversity, number of botanic families.

Peña et al. (2005) evaluating microbial respiration as an indicator of soil quality in the forest ecosystem showed that the increase in litter and organic matter content contributed to higher values of $\mathrm{CO}_{2}$ production in samples of the more advanced stages of vegetation and that these differences are the result of the forest's evolutionary process. Analyzing the 
Table 3. Average values of $\mathrm{CO}_{2}$ production and soil moisture in area with conilon coffee, Brachiaria sp. pasture and Atlantic Forest.

\begin{tabular}{lcc}
\hline Area & $\mathrm{CO}_{2}$ soil efflux & Soil moisture \\
\hline & $\mathrm{mg} \mathrm{m}^{-2} \mathrm{~h}^{-1}$ & $\%$ \\
Conilon coffee & $58.8 \mathrm{~b}$ & 19.5 \\
Brachiaria sp. pasture & $62.9 \mathrm{~b}$ & 34.3 \\
Atlantic forest & $83.7 \mathrm{a}$ & 9.5 \\
CV, \% & 3.26 & \\
Average & 66.0 & \\
\hline
\end{tabular}

Averages followed by the same letter do not differ by Tukey test at $5 \%$ probability.

microbial activity in soil under agroforestry systems, Silva et al. (2012) obtained similar results to that found in this study. The authors stated that forest areas presented higher $\mathrm{CO}_{2}$ emissions when compared to the areas of agroforestry systems. In studies carried out by Villatoro (2004) in the evaluation of $\mathrm{CO}_{2}$ flow in coffee agroforestry system in Guatemala, the author concluded that the soil respiration was higher, resulting in a higher respiratory activity. A study by Peixoto (2010) in soils, grassland and natural vegetation noted that the $\mathrm{CO}_{2}$ emission values on grassland $\left(11.02 \mathrm{mg} \mathrm{CO} \mathrm{Cg}_{2} \mathrm{~kg}^{-1}\right)$ were superior to the soils emissions by cultivation of sugarcane $\left(2.16 \mathrm{mg} \mathrm{CO}_{2} \mathrm{~kg}^{-1} \mathrm{~h}^{-1}\right)$, and in the same study it was verified that of 11 analyzed soils, seven presented greater respiration in forest condition. Fialho et al. (2006) found higher $\mathrm{CO}_{2}$ flux in native forest conditions than in planted area with banana in all depths evaluated. Gama-Rodrigues et al. (2008) when comparing the effect of different vegetation cover on the chemical and microbial attributes of a Red-Yellow Latosol, obtained superior values of respiration for grassland when compared in cultivated soils.

\section{CONCLUSIONS}

The highest magnitudes of $\mathrm{CO}_{2}$ efflux were observed at flowering, fruit maturation and harvest phases, with the harvest phase being responsible for the highest average $\mathrm{CO}_{2}$ emission. The possible explanation for high $\mathrm{CO}_{2}$ emissions are related to the increase in soil moisture recorded on the days of the evaluations and the amount of biomass collected, showing that the variables were related.

The $\mathrm{CO}_{2}$ emission from the Atlantic forest sample was higher than the emissions from the area planted with conilon coffee and pasture, probably due to the quality of the organic matter, as well as other climatic and microclimatic factors provided by the living and dead vegetation covering the ground.

\section{ACKNOWLEDGEMENT}

To the Foundation for Support to Research and Innovation of Espírito Santo (Edital Fapes No 006/2014 - Universal Individual Project of Research) for the financial assistance of funding and research grant.

\section{REFERENCES}

Arneth, A., Sitch, S., Pongratz, J., Stocker, B.D., Ciais, P., Poulter, B., et al. 2017. Historical carbon dioxide emissions caused by land-use changes are possibly larger than assumed. Nature Geoscience 10(2):79-84.

Belizário, M. 2013. Estoque de carbono no solo e fluxo de gases de efeito estufa no cultivo de café $143 \mathrm{f}$. Tese de doutorado. Escola Superior de Agricultura “Luiz de Queiroz”, Universidade de São Paulo (USP), São Paulo, Brasil.

Borges, A.L., Kiehl, J.C., e Souza, L.S. 1999. Alteração de propriedades físicas e atividade microbiana de um latossolo amarelo álico após o cultivo com fruteiras perenes e mandioca. Revista Brasileira de Ciência do Solo 23(1):1019-1025.

Brasil. 2009. Inventário brasileiro das emissões e remoções antrópicas de gases de efeito estufa. Ministério da Ciência e Tecnologia, São Paulo, São Paulo, Brasil. Available at http://pagina22.com.br/wp-content/uploads/2009/11/inventario1.pdf (accessed 9 October 2016).

Buysse, P., Flechard, C.R., Hamon, Y., and Viaud, V. 2016. Impacts of water regime and land-use on soil $\mathrm{CO}_{2}$ efflux in a small temperate agricultural catchment. Biogeochemistry 130(3):267-288.

Campana, M.M., Santos, R.H.S., Freitas, G.B., Martinez, H.E.P., Botero, C.J., e Garcia, S.L. 2007. Análise comparativa das características da serrapilheira e do solo em cafezais (Coffea arabica L.) cultivados em sistema agroflorestal e em monocultura, na Zona da Mata Minas Gerais. Revista Árvore 31(5):805-812. 
Chang, J., Ciais, P., Viovy, N., Vuichard, N., Herrero, M., Havlík, P., et al. 2016. Effect of climate change, $\mathrm{CO}_{2}$ trends, nitrogen addition, and land-cover and management intensity changes on the carbon balance of European grasslands. Global Change Biology 22(1):338-350.

CONAB. 2016. Acompanhamento da safra brasileira de café, segundo levantamento. Companhia Nacional de Abastecimento (CONAB), Brasília, Brasil. Agosto de 2016. Available at http://www.sapc.embrapa.br/arquivos/consorcio/levantamento/ Boletim_cafe_maio_2016.pdf (accessed 14 October 2016).

Davidson, E.A., Savage, K., and Verchot, L.V. 2002. Minimizing artifacts and biases in chamber-based measurements of soil respiration. Agricultural and Forest Meteorology 113(1):21-37.

Drake, J.E., Oishi, A.C., Giasson, M.A., Oren, R., Johnsen, K.H., and Finzi, A.C. 2012. Trenching reduces soil heterotrophic activity in a loblolly pine (Pinus taeda) forest exposed to elevated atmospheric $\left(\mathrm{CO}_{2}\right)$ and $\mathrm{N}$ fertilization. Agricultural and Forest Meteorology 165:43-52.

Dryden, R., Morgan, M.G., Bostrom, A., and Bruin, W.B. 2017. Public perceptions of how long air pollution and carbon dioxide remain in the atmosphere. Risk Analysis 38(3):525-534.

Embrapa. 2013. Sistema brasileiro de classificação de solos. 3 $3^{a}$ ed. Empresa Brasileira de Pesquisa Agropecuária (Embrapa), Embrapa Solos, Rio de Janeiro, Rio de Janeiro, Brasil.

Ferrao, R.G., Fonseca, A.F.A., Bragança, S.M., Ferrão, M.A.G., Muner, L.H. (eds.) 2007. Café conilon. 702 p. Incaper, Vitória, Espírito Santo, Brasil.

Ferreira, C.R.P.C., Antonino, A.C.D., Sampaio, E.V.D.S.B., Correia, K.G., Lima, J.R.D.S., Soares, W.D.A., et al. 2018. Soil CO 2 efflux measurements by alkali absorption and infrared gas analyzer in the Brazilian semiarid region. Revista Brasileira de Ciência do Solo 42:e0160563.

Fialho, J.S., Gomes, V.F.F., Oliveira, T.S., e Silva Junior, J.M.T. 2006. Indicadores de qualidade do solo em áreas sob vegetação natural e cultivo de bananeiras na Chapada do Apodi, CE. Revista Ciência Agronômica 37(3):257-260.

Forkel, M., Carvalhais, N., Rödenbeck, C., Keeling, R., Heimann, M., Thonicke, K., et al. 2016. Enhanced seasonal $\mathrm{CO}_{2}$ exchange caused by amplified plant productivity in northern ecosystems. Science 351(6274):696-699.

Gama-Rodrigues, E.F., Gama-Rodrigues, A.C., Paulino, G.M., e Franco, A.A. 2008. Atributos químicos e microbianos de solos sob diferentes coberturas vegetais no norte do Estado do Rio de Janeiro. Revista Brasileira de Ciência do Solo 32(1):1521-1530.

Iqbal, J., Hu, R., Lin, S., Hatano, R., Feng, M., Lu, L., et al. 2009. $\mathrm{CO}_{2}$ emission in a subtropical red paddy soil (Ultisol) as affected by straw and N-fertilizer applications: a case study in Southern China. Agriculture, Ecosystems and Environment 131(1):292-302.

Jia, H., Guo, H., Walsh, M.J., Bennett, J., Zhang, Y., and Wang, G. 2018. Long-term maize stalk retention reduces seedtime soil respiration. Chilean Journal of Agricultural Research 78(3):350-359.

Kirschbaum, M.U. 1995. The temperature dependence of soil organic matter decomposition, and the effect of global warming on soil organic C storage. Soil Biology and Biochemistry 27(6):753-760.

La Scala, J.N., Bolonhezi, D., and Pereira, G.T. 2006. Short-term soil $\mathrm{CO}_{2}$ emission after conventional and reduced tillage of a no till sugar cane area in Southern Brazil. Soil and Tillage Research 91(1):244-248.

McKnight, J.Y., Harden, C.P., and Schaeffer, S.M. 2017. Soil $\mathrm{CO}_{2}$ flux trends with differences in soil moisture among four types of land use in an Ecuadorian páramo landscape. Physical Geography 38(1):51-61.

Moyano, F.E., Manzoni, S., and Chenu, C. 2013. Responses of soil heterotrophic respiration to moisture availability: An exploration of processes and models. Soil Biology and Biochemistry 59:72-85.

Oliveira, B.G., Carvalho, J.L.N., Cerri, C.E.P., Cerri, C.C., and Feigl, B.J. 2013. Soil greenhouse gas fluxes from vinasse application in Brazilian sugarcane areas. Geoderma 200-201(1):77-84.

Panosso, A.R., Marques Jr., J., Milori, D.M.B.P., Ferraudo, A.S., Barbieri, D.M., Pereira, G.T., et al. 2011. Soil CO 2 emission and its relation to soil properties in sugarcane areas under Slash-and-burn and Green harvest. Soil and Tillage Research 111(2):190-196.

Peixoto, F.G.T. 2010. Biomassa microbiana e atividade enzimática em solos do estado de São Paulo sob vegetação nativa e cultivados. 69 f. Tese. Universidade Estadual Paulista, São Paulo, Brasil.

Peña, M.L.P., Marques, R., Jahnel, M.C., e Anjos, A. 2005. Respiração microbiana como indicador da qualidade do solo em ecossistema florestal. Floresta 35(1):117-127.

Raj, A. 2016. Climate change: cause, impact and mitigation strategies. South Indian Journal of Biological Sciences 2(4):363-367.

Sales, R.A., Oliveira, E.C., Delgado, R.C., Leite, M.C.T., Ribeiro, W.R., and Berilli, S.S. 2018. Sazonal and interanual rainfall variability for Colatina, Espirito Santo, Brazil. Scientia Agraria 19(2):186-196.

Signor, D., Pissioni, L.L.M., e Cerri, C.E.P. 2014. Emissões de gases de efeito estufa pela deposição de palha de cana-de-açúcar sobre o solo. Bragantia 73(1):113-122.

Silva, R.D.C.B., Lopes, A.P., Silva, K.K.A., Silva, T.C.F.S., Aragão, C.A., Dantas, B.F., et al. 2017. Crescimento inicial de plântulas de melancia submetidas ao aumento da temperatura e concentrações de $\mathrm{CO}_{2}$. Magistra 27(1):33-43.

Silva, M.S.C., Silva, E.M.R., Pereira, M.G., e Silva, C.F. 2012. Estoque de serapillheira e atividade microbiana em solo sob sistemas agroflorestais. Floresta e Ambiente 19(4):431-441. 
Stout, B., Lal, R., and Monger, C. 2016. Carbon capture and sequestration: The roles of agriculture and soils. International Journal of Agricultural and Biological Engineering 9(1):1-8.

Villatoro, A.M.A. 2004. Matéria orgânica e indicadores microbiológicos da qualidade do solo na cultura de café sob manejo agroflorestal e orgânico. $166 \mathrm{f}$. Tese de doutorado. Universidade Federal Rural do Rio de Janeiro, Rio de Janeiro, Brasil.

Zheng, X., Zhao, C., Peng, S., Jian, S., Liang, B., Wang, X., et al. 2014. Soil $\mathrm{CO}_{2}$ efflux along an elevation gradient in Qinghai spruce forests in the upper reaches of the Heihe River, northwest China. Environmental Earth Sciences 71(5):2065-2076. 